\title{
Assessment of completion of forms requesting skin biopsies
}

\section{Avaliação do preenchimento de solicitações de biópsias da pele}

\author{
Daniel Almeida Schettini ${ }^{1}$ \\ José Carlos Gomes Sardinha ${ }^{3}$ \\ Felicien Vasques ${ }^{5}$
}

\author{
Antonio Pedro Mendes Schettini ${ }^{2}$ \\ Luiz Carlos de Lima Ferreira ${ }^{4}$ \\ Luena Xerez ${ }^{6}$
}

\begin{abstract}
BACKGROUND: Information contained in request forms for histopathological examinations is essential for interpreting tissue changes observed in microscopy.

Овјестіле: To determine the adequacy of information provided on forms requesting skin biopsies.

METHOD: Assessment, in two health institutions, of 647 forms requesting skin biopsies in order to determine the completeness on the forms of the clinical details/items considered necessary for undertaking skin biopsies.

RESUlTS: Of the total 18 items on the forms, 7 were found to relay complete information in under $10 \%$ of the forms and only 9 items were correctly completed in over $80 \%$ of the requests.

CONCLUSION: We concluded that information on many of the essential items required for a correct interpretation of the anatomopathologic examination was missing from the request forms.

Keywords: Biopsy; Microscopy; Skin abnormalities

Resumo: FundAmENTOS: As informações contidas nas requisições de exames histopatológicos são fundamentais para a interpretação das alterações teciduais observadas na microscopia.

OвJетіvo: Verificar a frequência do preenchimento de itens de requisições de biópsias da pele.

MÉTODO: Avaliação do preenchimento de 647 solicitações de biópsias de pele, em duas instituições de saúde, em relação aos itens considerados necessários.

RESultados: De um total de 18 itens avaliados, 7 foram preenchidos em menos de $10 \%$ das requisições e 9 foram preenchidos corretamente em mais de $80 \%$ das requisições.

Conclusão: Verificou-se uma insuficiência do preenchimento de itens fundamentais para uma interpretação adequada do exame anatomopatológico.

Palavras-chave: Anormalidades da pele; Biópsia; Microscopia
\end{abstract}

\section{INTRODUCTION}

In everyday medical practice, the histopathological examination is mainly used as an auxiliary means of diagnosis. It also has other uses, such as to assist prognosis and to guide the most appropriate choice of therapy. Werner B.(2009) points to other benefits such as enhanced diagnostic certainty and patients feeling more confident with their doctor's procedures. ${ }^{1}$

Proper completion of the request forms is essential for undertaking an effective test, since correct patient identification, clinical data and the results of complementary laboratory tests all contribute to the interpretation of morphological changes in tissue. (Michalany, 2000; Brasileiro Filho et al., 1993). ${ }^{2,3}$ Fillus Neto \& Guedes (2005) view the clinician's request for a histopathological examination as a call for an expert opinion and, given that pathologists are unable to see the patient in person, they

\footnotetext{
Received on 30.06.2010.

Approved by the Advisory Board and accepted for publication on 21.09.2010.

* Work undertaken at the Faculty of Medicine, Federal University of Amazonas (UFAM), Manaus (AM), Brazil.

Conflict of interest: None / Conflito de interesse: Nenbum

Financial funding: None / Suporte financeiro: Nenbum

Physician at the Manaus Air Force Hospital (HAMN), Manaus (AM), Brazil.

Master's Degree in Tropical Pathology, Dermatologist at the Alfredo da Matta Foundation (FUAM), Manaus (AM), Brazil

Physician at the Alfredo da Matta Foundation (FUAM), Manaus (AM), Brazil.

$\mathrm{PhD}$ in Anatomic Pathology, Professor of Anatomic Pathology, Federal University of Amazonas (UFAM), Manaus (AM), Brazil.

Statistician, Alfredo da Matta Foundation (FUAM), Manaus, AM, Brazil.

Psychologist at the Alfredo da Matta Foundation (FUAM), Manaus (AM), Brazil.

(C)2012 by Anais Brasileiros de Dermatologia
} 
obviously need detailed and accurate clinical information to be readily available. ${ }^{4}$

Studies reveal that many errors are made in filling out histopathology requests, such as negligence in completing items, faulty or incomplete information, poor or illegible handwriting, loss of biological material, mixed-up test results and mistakes regarding the topography of the lesions. In their assessment of 1825 requests for skin biopsies, Alves et al. (2004) found that 439 (24\%) failed to include basic information such as the clinical diagnostic hypothesis. ${ }^{5}$ Valenstein \& Meier (1999), found in the requests for histopathological examination of 114,934 patients (whose specimens were sent to laboratories participating in a pathology accreditation program) that $5 \%$ of the forms were incorrectly completed, compromising the final diagnosis. ${ }^{6}$ These authors concluded that if such errors (although relatively few in number) could occur in laboratories with rigorous quality control standards, it was entirely possible that the number of errors would be greater in other less demanding laboratories. Nakhleh et al.(1999) point out that neglecting to provide detailed clinical information is largely responsible for medical malpractice claims involving pathologists. According to the same authors, periodic assessments by the College of American Pathologists revealed that $10 \%$ of specimens submitted to pathology were not even accompanied by request forms.

In Brazil, various documents routinely used in medical practice such as death certificates and mandatory disease notifications contain errors which undermine the quality of information inputted into databases for designing and evaluating health programs. According to Niobey et al. (1990), doctors pay scant regard to completing these documents correctly, revealing their ignorance of the importance of this information. $^{8}$

The present study aimed to determine the adequacy of information provided on forms requesting skin biopsies that were received in two pathology laboratories - one public and the other private, both located in Manaus in the state of Amazonas.

\section{METHODS}

The universe of the study consisted of the requests for pathology received, processed and analyzed in 2005 at the Anatomopathology Laboratory of the Federal University of Amazonas and at a private laboratory, both located in the city of Manaus.

Of the 12,000 biopsies performed during this period in the two laboratories, 647 requests were selected at random. The equation $\mathrm{K}=\mathrm{N} / \mathrm{n}$ was used to define the systematic sampling interval of the participants, with one in every 18 requests selected. Our task was to verify whether the request forms contained the items considered necessary (according to Michalany J.) for the test to be effective: name, sex, color, age, marital status, home town and/or place where residing, occupation, name of referring physician, date of surgery, type of material and its delivery date in the laboratory, date of onset of illness or lesion, results of other laboratory tests, previous treatments and diagnostic hypotheses based on clinical examination. ${ }^{2}$

\section{RESULTS}

Of the 647 requests for histopathological examinations, 113 were from the Institution of Public Health Institution Network and 534 from a private laboratory.

$100 \%$ of the request forms studied revealed one or more gaps in the completion of the items assessed. (Table 1).

One group of items revealed less than 10\% completion: radiology $0.6 \%$, marital status $2.0 \%$, home town/place of residence $2.16 \%$, profession 2.16\%; complementary tests $3.09 \%$, nationality $3.09 \%$ and color of patient $8.3 \%$.

Two items (diagnostic hypothesis and clinical data) were completed correctly in $28.7 \%$ and $65.22 \%$ of the forms respectively.

A further group of items presented a completion rate of over $80 \%$ : originating organ of the material $83.62 \%$, sex $89.5 \%$, age $89.6 \%$, name $97.2 \%$, requesting institution $97.2 \%$, requesting pysician $98 \%$, biopsy date $98.8 \%$, date of delivery of material $99.0 \%$, and signature of the physician who prepared the report $99.5 \%$.

A higher completion rate was observed from the public laboratory regarding color, marital status, nationality, profession, clinical diagnosis and clinical data compared to the requests received from the private laboratory, and this difference was statistically significant. Meanwhile, the items describing the requesting institution, together with the signature of the doctor who prepared the report, were completed more often in the forms from the private laboratory, with the difference being statistically significant (Table 1 ).

\section{DISCUSSION}

Our results show that none of the request forms contained all the properly-completed items vital for correct interpretation of histopathological changes.

One group of items revealed less than 10\% completion: radiology, marital status, home town/place of residence, profession, complementary tests, nationality and color. This low level of completion affects the final result of the examination in a 
TABLE 1: Number and percentage of completed items studied (public and private laboratories)

\begin{tabular}{|c|c|c|c|c|c|c|c|}
\hline \multirow{3}{*}{ Items assessed } & \multicolumn{6}{|c|}{ Number and Level (\%) of Completion } & \multirow[b]{3}{*}{$\mathrm{p}$} \\
\hline & \multicolumn{2}{|c|}{$\begin{array}{l}\text { Public laboratory } \\
(N=113)\end{array}$} & \multicolumn{2}{|c|}{$\begin{array}{l}\text { Private laboratory } \\
(N=534)\end{array}$} & \multicolumn{2}{|c|}{$\begin{array}{l}\text { Total } \\
(N=647)\end{array}$} & \\
\hline & fi & $\%$ & fi & $\%$ & fi & $\%$ & \\
\hline 1. Name & 111 & 98.2 & 518 & 97.0 & 629 & 97.2 & $0.752 * *$ \\
\hline 2. Sex & 103 & 91.2 & 476 & 89.1 & 579 & 89.5 & $0.526 *$ \\
\hline 3. Color & 16 & 14.2 & 38 & 7.1 & 54 & 8.3 & $0.023 *$ \\
\hline 4. Age & 96 & 85.0 & 484 & 90.6 & 580 & 89.6 & $0.072 *$ \\
\hline 5. Marital status & 7 & 6.2 & 7 & 1.3 & 14 & 2.0 & $0.005 * *$ \\
\hline 6. Nationality & 8 & 7.1 & 12 & 2.2 & 20 & 3.09 & $0.013 * *$ \\
\hline 7. Home town/place of residence & 3 & 2.7 & 11 & 2.1 & 14 & 2.16 & $0.720 * *$ \\
\hline 8. Profession & 7 & 6.2 & 7 & 1.3 & 14 & 2.16 & $0.005 * *$ \\
\hline 9. Requesting Institution & 104 & 92 & 524 & 98.1 & 628 & 97.2 & $0.002 * *$ \\
\hline $\begin{array}{l}\text { 10. Identification of Requesting } \\
\text { Physician }\end{array}$ & 109 & 96.5 & 525 & 98.3 & 634 & 98.0 & $0.258 * *$ \\
\hline 11. Date of Biopsy & 111 & 98.2 & 528 & 98.9 & 639 & 98.8 & $0.634 * *$ \\
\hline 12. Delivery Date of Material & 111 & 98.2 & 530 & 99.3 & 641 & 99.0 & $0.282 * *$ \\
\hline $\begin{array}{l}\text { 13. Organ: area of collection } \\
\text { or removal }\end{array}$ & 95 & 84.2 & 446 & 83.5 & 541 & 83.62 & $0.886 *$ \\
\hline 14. Diagnostic Hypothesis & 86 & 76.1 & 336 & 62.9 & 422 & 65.22 & $0.008 *$ \\
\hline 15. Clinical Data & 56 & 49.6 & 130 & 24.3 & 186 & 28.7 & $<0.001 *$ \\
\hline 16. Complementary tests & 5 & 4.4 & 15 & 2.8 & 20 & 3.09 & $0.370 * *$ \\
\hline 17. Radiological Data & 2 & 1.8 & 2 & 0.4 & 4 & 0.6 & $0.143 * *$ \\
\hline 18. Signature of Physician & 110 & 97.3 & 534 & 100 & 644 & 99.5 & $0.005 * *$ \\
\hline
\end{tabular}

f i Absolute simple frequency f I; * Chi-square test; ** Fisher's exact test; P values $<0.05$ indicating statistical difference at $5 \%$.

number of different ways.

Complementary diagnostic tests, including radiology exams, provide information which enhance the value of clinical data and assist in the interpretation of histopathologic findings. A positive VDRL test, for example, can reveal plasma cells around dermal vessels, assisting the diagnosis of secondary syphilis. The home town/place of residence, marital status, nationality and skin color are also important, given that some diseases are more common in certain geographic regions, while patients of a particular color and those with certain behavior patterns or personal habits are more prone to certain diseases. These items are not completed on the forms probably because the requesting physician is not fully aware of the importance of the data in the formulation of the histopathological diagnosis. Studies on death certificate data reveal that many doctors consider the required information to be a bureaucratic irrelevance, with no bearing on subsequent efforts to diagnose e.g. the causes of death or to produce a solid and reliable database. ${ }^{9}$

The completion on the request forms of other items such as diagnosis and clinical data can be classified as 'intermediate completion'. These two items are in fact essential for histological analysis, and the lack of information obviously limits its interpretation. The clinical diagnosis and history, together with the physical examination, serve as a screening method for selecting possible histopathological diagnoses and can exclude or provide greater consistency to a particular diagnostic hypothesis. Some assumptions can be offered to explain why this data is less frequently supplied: (a) lack of understanding by the referring physician of the potential, as well as the limitations, of histopathology; and (b) being unprepared to undertake collaborative interdisciplinary work. It is likely that some requesting physicians optimistically reckon that microscopic analysis is the ultimate deciding factor and therefore the information contained in the request is of minimal importance. In other words, the pathologist is required to shoulder all the responsibility for the outcome.

A third group of items showed an acceptable completion rate (over $80 \%$ ): the organ of origin of the material, gender, age, name, requesting institution, requesting physician, date of biopsy, date of delivery of material and signature of the physician who prepared the report. Many of these items relate to the process of identification and processing of the material 
and can be considered as data that are more important from an administrative standpoint. One reason for the higher level of completion of these items could be that they can be filled out by ancillary staff and not necessarily by the requesting physician. Authors who have examined other medical documents highlight the important role of the physician in completing forms correctly since he is the first link in the information chain. Discrepancies or errors on the forms are attributed to limited awareness of the importance of the results of this information, arising perhaps from a lack of emphasis on correct completion of these documents during medical training. ${ }^{10}$ It is worth adding at this point that no standardized application form exists covering all the items considered important for a histopathological examination.

Our findings revealed that some items were completed more often in the Public Laboratory. A plausible explanation for this may be that this laboratory belongs to a medical teaching facility, in which case the individuals signing the request forms might be more aware of the importance of filling out the requests correctly.

\section{CONCLUSION}

The available literature on this subject and the above findings highlight the many weaknesses in the completion of certain medical documents, including request forms for pathologic examinations. Certain steps could be taken to remedy this situation, e.g.: (a) standardization of the pathology request forms; (b) receiving-laboratories to deal only with appropriatelycompleted forms; and (c) greater emphasis at medical school and during post-training on the importance of correct completion of the forms requesting a histopathologic examination.

\section{REFERENCES}

1. Werner B. Biópsia de pele e seu estudo histológico. Por quê? Para quê? Como? Parte I. An Bras Dermatol. 2009;84:391-5.

2. Michalany J. Anatomia Patológica Geral na prática médico-cirúrgica. 2 ed. São Paulo: Artes Médicas; 2000

3. Brasileiro Filho G, Pereira FEL, Pitella JEH, Bambirra EA, Barbosa AJA. Bogliolo, Patologia Geral. 7 ed. Rio de Janeiro: Guanabara Koogan; 2006.

4. Sbd. Org [Internet]. Sociedade Brasileira de Dermatologia. Manual de conduta. Biópsia. [acesso 29 Jun. 2010). Disponível em: http://www3.sbd.org.br/Download/Pdf/ManualConduta/Biopsia.pdf.

5. Alves JR, Hida M, Nai GA. Diagnóstico Clínico e Anatomopatológico: Discordâncias. Rev Assoc Med Bras. 2004;50:178-81.

6. Valenstein P, Meier F. Outpatient order accuracy: A College of American Pathologists Q-Probes study of requisition order accuracy in 660 institutions. Arch Pathol Lab Med. 1999;123:1145-50.

7. Nakhleh RE, Gephardt G, Zarbo RJ. Necessity of clinical information in surgical pathology. Arch Pathol Lab Med. 1999;123: 615-9.

8. Niobey FML, Cascão AM, Duchiade MP, Sabroza PC. Qualidade do preenchimento de atestados de óbito de menores de 1 ano na região metropolitana do Rio de Janeiro. Rev Saúde Pública São Paulo. 1990;24:311-8.
9. Stuque OC, Cordeiro JA, Cury PM. Avaliação dos erros ou falhas de preenchimento dos atestados de óbitos feitos pelos clínicos e patologistas. J Bras Patol Md Lab. 2003;39:361-4.

10. Laurenti R. A análise da mortalidade por causa básica ou por causas múltiplas. Rev Saúde Públ São Paulo. 1974;8:421-35.

How to cite this article/Como citar este artigo: Schettini DA, Schettini APM, Sardinha JCG, Ferreira LCL, Vasques F, Xerez L. Assessment of completion of forms requesting skin biopsies. An Bras Dermatol. 2012;87(1):115-8. 